\title{
Gastrointestinal Emulsion Dosage Form
}

National Cancer Institute

\section{Source}

National Cancer Institute. Gastrointestinal Emulsion Dosage Form. NCI Thesaurus. Code C149528.

Liquid preparation consisting of an emulsion intended for administration to the stomach or duodenum by means of a suitable applicator. 